\title{
Sistem Informasi Pengurusan Surat Pengantar Berbasis Framework Codeigniter Guna Meningkatan Kualitas Pelayanan kepada Masyarakat
}

\author{
Andesita Prihantara ${ }^{1}$, Abdul Aziz ${ }^{2}$ \\ ${ }^{1,2}$ Jurusan Teknik Informatika, Politeknik Negeri Cilacap, Cilacap \\ 1,2Jln. Dr. Soetomo, No. 1 Sidakaya Cilacap, 537992, Indonesia \\ email: ${ }^{1}$ andesita.p@ politeknikcilacap.ac.id, ${ }^{2}$ abdul.stu@ politeknikcilacap.ac.id \\ Received: 30 Juli 2018; Revised: 1 Oktober 2018; Accepted: 20 Oktober 2018 \\ Copyright @2018, Politeknik Harapan Bersama, Tegal
}

\begin{abstract}
The guide letter has an important role in the administration of population administration at the village level. The letter of introduction is a proof of recognition from the Chairman of RT, RW and Village Office Chairman against the residents domiciled in the area. The management of guide letter and residents' domicile data in Bandasari Village has not been well managed. The data of introductory letters and immigrants are still managed and stored in each Chariman RT. In this research, developed Information System of Guidance Letter Handling Village Management Bandasari aims to manage data introduction letter and data of immigrants in the village Bandasari. System development using System Development Life Cycle (SDLC) method with waterfall process model and blackbox testing method. Based on the tests conducted, it is known that the system will be developed to assist fast the People, Chairman of RT, RW and Village chief in managing the data of guidace letters and migrant residents data, because data saved in one database and can be access by user.
\end{abstract}

Abstrak - Surat pengantar berperan penting dalam pengelolaan administrasi kependudukan di tingkat desa. Surat pengantar adalah bukti pengakuan dari Ketua RT, Ketua RW dan Kantor Desa terhadap warga yang berdomisili di daerahnya. Pengelolaan surat pengantar dan data domisili warga di Desa Bandasari belum terkelola dengan baik. Data surat pengantar dan warga pendatang masih terkelola dan tersimpan pada masing-masing Ketua RT. Pada penelitian ini, dikembangkan Sistem Informasi Pengurusan Surat Pengantar Berbasis Framework Codeigniter yang bertujuan untuk mengelola data surat pengantar dan data warga pendatang di Desa Bandasari. Pengembangan sistem menggunakan metode System Development Life Cycle (SDLC) dengan model proses atau paradigma waterfall dan metode pengujian menggunakan blackbox testing. Berdasarkan pengujian yang dilakukan, diketahui sistem yang akan dikembangkan dapat membantu mempercepat Warga, Ketua RT, Ketua RW dan Kantor Desa dalam mengelola data surat pengantar dan data warga pendatang Karena proses pencatatan data akan disimpan di satu database sehingga data bisa diakses dari masing-masing pengguna.

Kata Kunci - Surat Pengantar, Pengelolaan, Administrasi, Warga, Framework, SDLC.

*) Corresponding Author: (Andesita Prihantara)

Email: andesita.p@politeknikcilacap.ac.id

\section{PENDAHULUAN}

Desa Bandasari adalah salah satu desa yang berada di Kecamatan Dukuhturi Kabupaten Tegal. Sebagai salah satu desa yang berada di Tegal, daerah ini tengah menjadi sorotan terhadap berbagai pelaksanaan program berbasis teknologi informasi. Disisi lain masih banyak pelayanan warga yang menggunakan sistem manual dalam menjalankan pelayananya, seperti ketika warga akan membuat berbagai macam surat (Kartu Tanda Penduduk, Nikah, Kartu Keluarga, Akte Kelahiran dan Surat Kematian). Dalam pengurusan seperti ini akan di butuhkan yang namanya surat pengantar, surat pengantar ini dibuat oleh Ketua RT dan disetujui atau di konfirmasi oleh Ketua RT (Rukun Tetangga), Ketua RW (Rukun Warga) dan Kantor Desa. Jika menggunakan proses seperti ini akan memakan banyak waktu, tenaga dan biaya.

Alur pengurusan surat pengantar yang saat ini masih diterapkan di masyarakat adalah ketika warga ingin membuat surat pengantar di Ketua RT, maka warga tersebut harus datang ke rumah ketua RT dengan membawa Kartu Tanda Penduduk (KTP). Kemudian ketua RT akan mencetakan surat pengantar yang nantinya akan di tuliskan sesuai dengan kebutuhan. Kemudian surat pengantar tersebut ditandatangani dan cap stempel Ketua RT, jika pengurusan surat pengantar di tingkat RT sudah selesai maka warga harus melanjutkan ke tingkat RW untuk meminta persetujuan berupa tanda tangan ketua RW dan stempel RW. Jika proses sudah selesai maka selanjutnya warga harus menuju ke tingkat kelurahan untuk menyelesaikan proses pembuatan surat yang dibutuhkan. Pada sesi ini surat pengantar sudah selesai, dengan persetujuan lengkap dari Ketua RT, Ketua RW, dan Kepala Desa. Namun dengan metode pengurusan seperti ini akan menyita banyak waktu. Misalnya, ketika warga ingin membuat surat pengantar, maka warga harus meluangkan waktu yang ada untuk mengurus surat itu ke rumah ketua RT kemudian Ketua RW, bahkan hingga ke Kelurahan. Tenaga, warga juga harus mengeluarkan banyak tenaga untuk mengurus surat pengantar. Karena harus ke rumah ketua RT dan rumah ketua RW.

Berdasarkan fakta di lapangan, proses yang berjalan tidak sesuai dengan Undang-undang Republik Indonesia Nomor 24 
tahun 2013 tentang administraasi kependudukan, Yang berbunyi bahwa dalam rangka mewujudkan tertib administrasi secara nasional Negara Kesatuan Republik Indonesia yang berdasarkan Pancasila dan UUD 1945, pada hakikatnya berkewajiban memberikan perlindungan dan pengakuan terhadap penentuan status pribadi dan status hukum atas setiap peristiwa kependudukan dan peristiwa penting yang dialami oleh penduduk dan/atau Warga Negara Indonesia [1]. Ketua RW sering kali dilewati persetujuanya karena sulit untuk ditemui, sehingga pihak balai desa seringkali memaklumi, hal ini membuat Ketua RW tidak mengetahui secara lengkap surat pengantar apa saja yang telah dibuat di wilayahnya. Warga pendatang yang tinggal tidak tetap (kontrak) juga menjadi masalah, karena tidak tercatatnya identitas warga pendatang, hal ini terjadi karena tidak dilaporkanya dokumen identitas warga pendatang tidak tetap oleh pemilik rumah kontrakan, sehingga ketika warga pendatang tidak tetap ingin membuat surat pengantar tidak diperbolehkan, karena identitasnya tidak tercatat di Ketua RT

Berdasarkan masalah tersebut, maka di desa Bandasari sangat perlu untuk dibuat sebuah sistem informasi yang nantinya bagi warga akan mengurangi pengeluaran tenaga, waktu. Dengan sistem informasi data warga akan tersimpan rapi begitu juga dengan data warga pendatang tidak tetap, karena pemilik kontrakan tidak perlu melapor ke Ketua RT apabila ada warga pendatang baru, pemilik kontrakan hanya perlu untuk melapor lewat fitur didalam sistem informasi. Selain itu pengurusan surat pengantar juga akan lebih cepat dan juga menghilangkan pelanggaran terhadap Undangundang No 24 Tahun 2013 Tentang Administrasi Kependudukan dimana Ketua RW sering dilewati persetujuanya, padahal informasi surat pengantar yang pernah dibuat diwilayahnya, Ketua RW harus mengetahui.

\section{PENELITIAN YANG TERKAIT}

Penelitian analisa perancangan Otomatisasi Surat Pengantar RT berbasis SMS Gateway sebagai penerapan konsep Paperless Office adalah penelitian yang dilatar belakangi oleh permasalahan pada penggunaan kertas yang dapat merusak lingkungan, karena untuk membuat kertas satu rim dibutuhkan satu buah pohon, sehingga dengan sistem ini diharapkan dapat mengurangi penggunaan kertas (Irawan, Yudie., 2015) [2]

Penelitian lain di lakukan oleh Junidar terkait perancangan sistem surat menyurat di Universitas U'Budiyah Indonesia, sistem ini bertujuan untuk mempermudah dalam mengelola surat dan memperbaiki administrasi surat menjadi lebih efektif dan efisien. Sistem informasi ini berfungsi untuk mengelola surat yang ada. Cara kerjanya hampir sama, namun penelitian ini pengerjaanya hanya sampai pada perancangan saja. [3]

Penelitian terkait data administrasi desa juga pernah dilakukan oleh Purwanto, Riyadi dari Politeknik Negeri Cilacap (PNC). Permasalahan yang terjadi adalah sering terjadinya duplikasi data yang membuat pencatatan data kependudukan di Desa Pandansari tidak efektif. Penelitian ini bertujuan untuk mencegah terjadinya duplikasi data kependudukan. Pada penelitian ini mengembangkan sistem sentralisasi database penduduk Desa Pandansari yang membantu Pemerintah Desa Pandansari dalam mengelola data penduduk secara terpusat [4].
Penelitian ini berbeda dengan penelitan yang sudah di sebutkan tadi karena yang pertama pada basis pengembangan yang di gunakan dalam penelitian ini akan berbasis web, juga penelitian ini akan sampai pada tahap pengkodean, selain itu pada pengembangan sistem informasi ini juga akan menambahkan fitur untuk memudahkan pemilik rumah kontrakan dalam melaporkan warga pendatang tidak tetap, dan hasil penelitian sistem pengurusan surat pengantar ini di harapkan nantinya bisa bermanfaat untuk warga dalam mengurus surat pengantar, juga akan mempermudah ketua RT, RW dan Pemerintah Desa dalam mengelola surat pengantar.

\section{METODE PENELITIAN}

Metode penelitian yang digunakan mencakup beberapa aspek seperti bahan penelitian yang berisi sumber data baik dari observasi maupun wawancara. Alat yang digunakan untuk penelitian dan terakhir jalan penelitian yang menggunakan konsep metodologi waterfall. Seluruh data masyarakat yang digunakan diambil dari lingkungan RT/RW dan Kantor Desa Bendasari Kecamatan Dukuhturi, Kabupaten Tegal.

\section{A. Bahan Penelitian}

Pada penelitian ini, bahan-bahan yang digunakan adalah sebagai berikut:

- Data penduduk RT01/RW01 yang didapat dari sensus keluarga pada tahun 2017.

- Data warga pendatang yang bertempat tinggal di rumah kontrakan diwilayah RT01/RW01 Desa Bandasari.

- Data jenis-jenis surat pengantar sesuai dengan kebutuhanya.

- Data riwayat pembuatan surat pengantar yang disimpan didalam buku besar Ketua RT.

- Alur kerja dari surat pengantar di tingkat Rukun Tetangga, Rukun Warga berdasarkan undang-undang no 24 tahun 2013 tentang tertib administrasi kependudukan.

\section{B. Alat Penelitian}

Alat yang digunakan dalam penelitian ini adalah seperangkat komputer yang memiliki spesifikasi cukup untuk menjalankan sistem operasi dan perangkat lunak yaitu Windows 10, Apache (Webserver), Mysql (Database Manajemen System), Sublime Text (Text Editor) dan Google Chrome (Browser).

\section{Jalan Penelitian}

Jalan penelitian adalah langkah-langkah yang akan diambil pada pelaksanaan penelitian. Jalan penelitian pada sistem informasi pengurusan surat pengantar Desa Bandasari menggunakan pemodelan waterfall, agar sistem yang dibuat dapat bermanfaat sesuai dengan kebutuhan pengguna/user. Sebagaimana ditunjukan pada Gbr 1. 


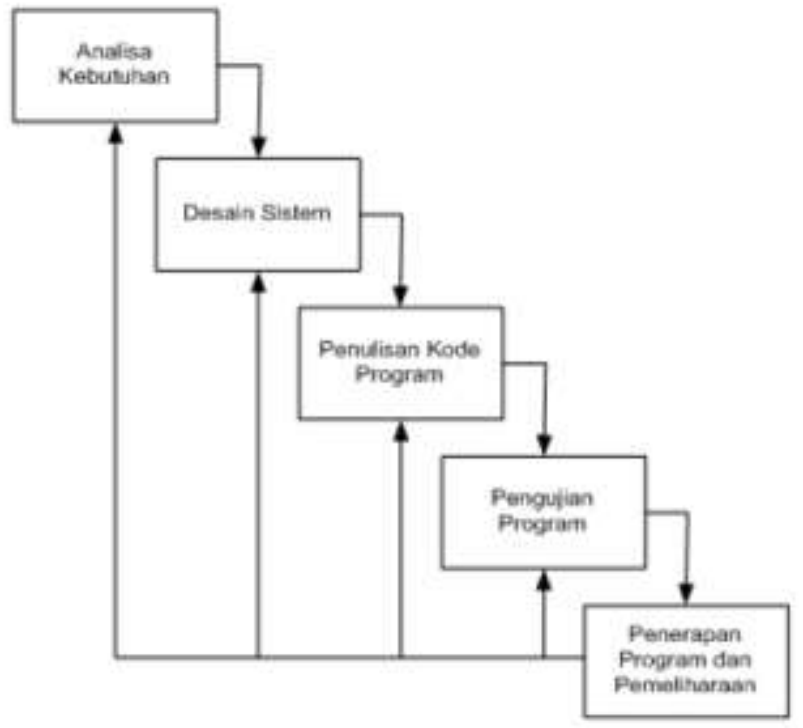

Gbr .1 Metode Pengembangan Model Waterfall [5]

\section{1) Analisa Kebutuhan (Analysis)}

Langkah ini merupakan analisa terhadap kebutuhan sistem. Pengumpulan data pada tahap ini bisa melakukan sebuah penelitian, wawancara atau study literatur. Seorang sistem analisis akan menggali informasi sebanyak-banyaknya dari user sehingga akan tercipta sebuah sistem komputer yang bisa melakukan tugas-tugas yang diinginkan oleh user tersebut [6]. Tahapan ini akan menghasilkan dokumen user reqruitment atau bisa dikatakan sebagai data yang berhubungan dengan keinginan user dalam pembuatan sistem. Dokumen inilah yang akan menjadi acuan sistem analisis untuk menterjemahkan kedalam bahasa pemrograman.

\section{2) Desain Sistem (Design)}

Proses desain sistem akan menerjemahkan syarat kebutuhan kesebuah perancangan perangkat lunak yang dapat diperkirakan sebelum dibuat coding. Proses ini berfokus pada: struktur data, arsitektur perangkat lunak, representasi interface, dan detail (algoritma) prosedural. Tahapan ini akan menghasilkan dokumen yang disebut software recruitment [7]. Dokumen inilah yang akan digunakan programmer untuk melakukan aktifitas pembuatan sistemnya.

\section{3) Penulisan Kode Program (Coding)}

Coding merupakan penerjemah design dalam bahasa yang bisa dikenali oleh komputer. Dilakukan oleh programmer yang akan menterjemahkan transaksi yang diminta oleh user. Tahapan inilah yang merupakan tahapan secara nyata dalam mengerjakan suatu sistem. Dalam artian penggunaan komputer akan dimaksimalkan dalam tahapan ini. Setelah pengkodean selesai maka akan dilakukan testing terhadap sistem yang telah kita buat tadi. Tujuan testing adalah menemukan kesalahan-kesalahan terhadap sistem tersebut dan kemudian bisa diperbaiki [8].

\section{4) Pengujian Program (Testing)}

Tahapan ini bisa dikatakan final dalam pembuatan sebuah sistem. Setelah melakukan analisa, design dan pengkodean maka sistem yang sudah jadi akan digunakan oleh user.

\section{5) Penerapan Program dan Pemeliharaan (Maintenance)}

Perangkat lunak yang sudah disampaikan kepada pelanggan pasti akan mengalami perubahan [9]. Perubahan tersebut bisa karena mengalami kesalahan karena perangkat lunak harus menyesuaikan dengan lingkungan (peripheral atau dengan sistem operasi yang baru) atau karena pelanggan membutuhkan perkembangan fungsional.

\section{Perancangan Sistem}

Perancangan sistem yang akan dikembangkan digambarkan dalam flowchart seperti yang ditunjukan pada Gbr. 2.

\section{1) Flowchart Proses Pelaporan Warga Pendatang Baru}

Rancangan flowchart pada Gbr. 2, menggambarkan alur proses pelaporan warga (Pemilik Rumah Kontrakan) atas warga pendatang baru yang menghuni rumahnya.

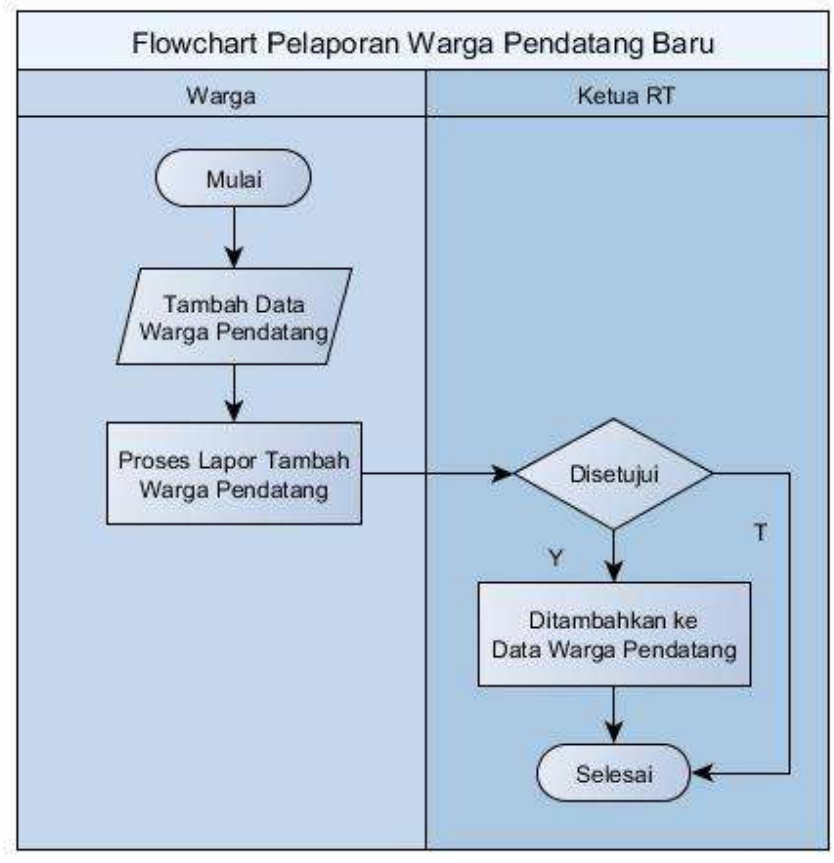

Gbr. 2 Flowchart lapor warga pendatang

Dimulai dari warga (Pemilik Rumah Kontrakan) menambahkan data warga pendatang baru berdomisili tidak tetap ke sistem. Kemudian pelaporan ini akan masuk ke dashboard Ketua RT. Jika Ketua RT sudah menyetujui informasi adanya penambahan data warga pendatang baru, maka data warga pendatang baru akan masuk ke daftar warga berdomisili tidak tetap.

\section{2) Flowchart Proses Pengurusan Surat Pengantar}

Rancangan flowchart pada Gbr. 3, menggambarkan alur proses pengurusan surat pengantar dari Bagian Ketua RT, Ketua RW sampai ke Kantor Desa di Desa Bandasari. 


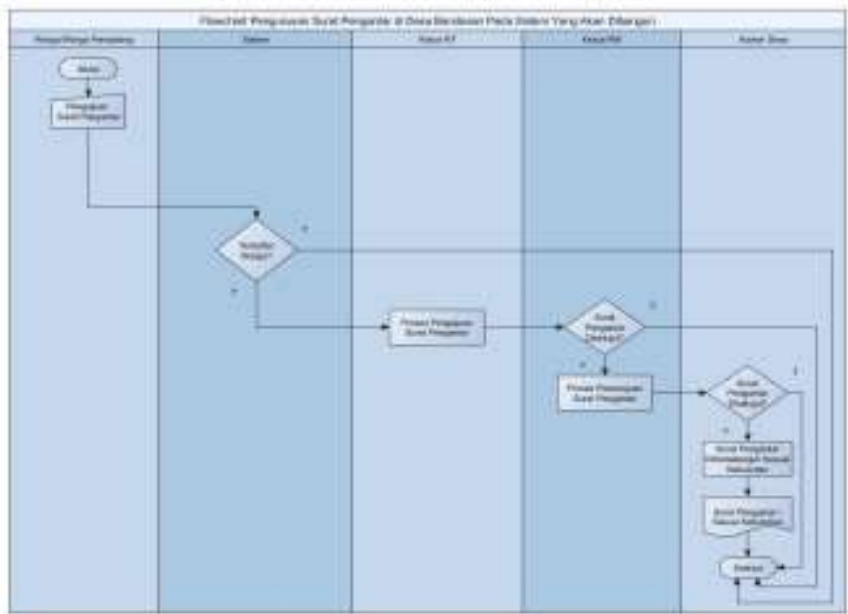

Gbr. 3 Flowchart pengajuan surat pengantar
Proses pengurusan surat pengantar yang akan dikembangkan dimulai dari warga yang akan mengajukan permohonan pembuatan surat pengantar dengan mengajukan data dirinya apakah sudah terdaftar sebagai warga setempat, proses pengecekan akan dilakukan oleh sistem, jika belum terdaftar maka proses selesai, jika sudah maka proses pengajuan permohonan surat pengantar dapat dilanjutkan dengan mengajukan permohonan dan data pengajuan akan dibuat dan disetujui oleh Ketua RT, kemudian data surat pengantar akan masuk ke Ketua RW, apabila Ketua RW menyetujui maka surat pengantar akan sampai ke Kantor Desa.

Rancangan sistem yang akan dikembangkan juga digambar dengan menggunakan Usecase Diagram dan Entity Relationship Diagram yang menjelaskan proses-proses yang dikembangkan dalam sistem dan perancangan basis data. Salah satu manfaat usecase diagram adalah memungkinkan penganalisis memahami interaksi antara sistem dan aktor [10].

\section{a. Use Case Diagram}

Use case adalah sebuah kegiatan yang dilakukan oleh sistem, biasanya menanggapi permintaan dari pengguna sistem [11]. Pada Gbr. 4 terdapat 10 use case dan 4 aktor, pada use case ini juga dijelaskan, bahwa setiap aktor yang akan melakukan aktivitasnya harus melakukan proses login atau verifikasi kependudukan (harus terdaftar sebagai warga) terlebih dahulu.

\section{b. Entity Relationship Diagram}

ERD berisikan komponen-komponen himpunan entitasentitas dan himpunan relasi yang masing-masing dilengkapi dengan atribut [12]. Entity Relationship Diagram (ERD) ini digunakan untuk membuat rancangan sistem dari tabel yang ada dalam database sistem yang telah dibuat, untuk memudahkan penulis dalam membuat rancangan alur data. Adapun rancangan ERD dari Sistem Informasi Pengurusan Surat Pengantar (SISUPER) dapat dilihat pada Gbr. 5.

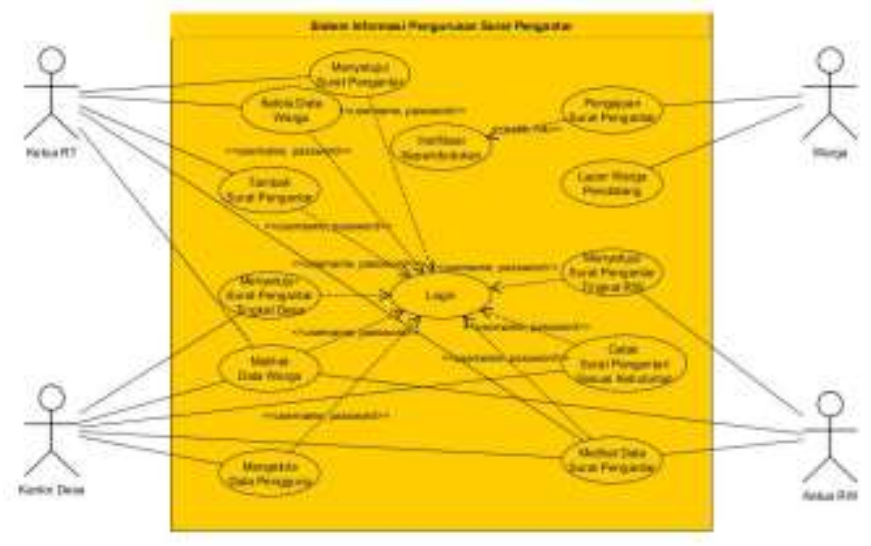

Gbr. 4 Use Case diagram sistem yang akan dikembangkan

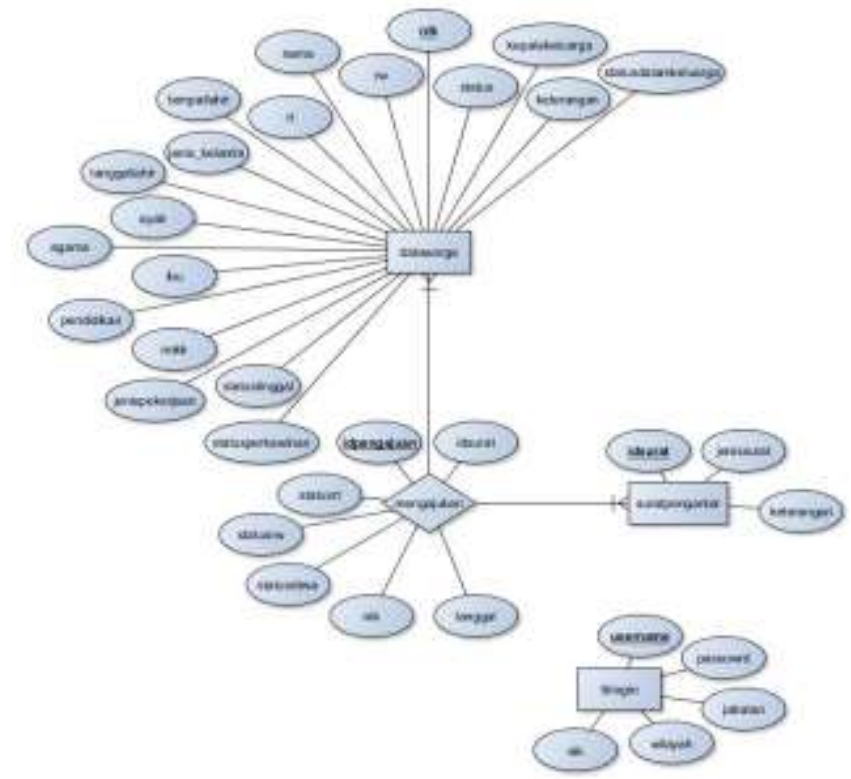

Gbr. 5 Entity Relationship Diagram sistem yang akan dikembangkan

ERD sistem informasi pengurusan surat pengantar Desa Bandasari (SISUPER) memiliki beberapa entitas yang saling berhubungan, diantaranya adalah datawarga, suratpengantar, tblogin. Entitas datawarga memiliki hubungan many to many, dimana satu atau beberapa warga dapat mengajukan satu atau beberapa surat pengantar, dan satu atau beberapa surat pengantar dapat diajukan oleh satu atau beberapa warga.

\section{HASIL DAN PEMBAHASAN}

Penelitian dilakukan dengan melakukan observasi dan wawancara dengan user untuk mengentahui alur dari proses sehingga dapat dijadikan acuan dalam melakukan proses pengelolaan data [13]. Hasil penelitian berupa aplikasi Sistem Informasi Pengurusan Surat Pengantar (SISUPER). Aplikasi ini dikembangkan untuk membantu warga dalam melakukan pengajuan surat pengantar dan melapor warga pendatang serta membantu Ketua RT, Ketua RW dan kantor Desa dalam mengelola warga pendatang dan pengurusan surat pengantar yang ada di Desa Bandasari. 


\section{A. Implementasi Perancangan Antarmuka}

Pada tahap ini penulis akan membahas mengenai hasil implementasi dengan menggunakan framework Codeigniter [14] dari Sistem Informasi Pengurusan Surat Pengantar Desa Bandasari adalah sebagai berikut:

1) Form Login

Pada proses login, pada bagian user (Ketua RT, Ketua RW, Kantor Desa) harus login menggunakan username dan password yang telah terdaftar pada sistem. Login berfungsi untuk authorization system bagi pengguna agar dapat mengakses content sesuai dengan bagian hak aksesnya. Tampilah form login dapat dilihat pada Gbr. 6.

\begin{tabular}{|l|}
\hline Login \\
Username \\
Username \\
Password \\
Password \\
Remember Password \\
\hline Login \\
\hline
\end{tabular}

Gbr. 6 Halaman form login

Gbr. 6 menjelaskan bahwa form login digunakan untuk hak akses pengguna untuk dapat masuk kedalam sistem dan mengakses menu-menu yang ada pada masing-masing halaman utama sesuai dengan hak akses pengguna, yaitu dengan mengisi username dan password kemudian menekan tombol login. Untuk semua pengguna pada masing-masing bagian harus login melalui form ini. Kemudian sistem akan memverifikasi username dan password yang dimasukan, berdasarkan wilayah dan hak aksesnya.

\section{2) Sub Mепu Tambah Surat}

Pada halaman menu tambah surat digunakan untuk menambahkan pengajuan surat pengantar, selain terdapat fitur pengajuan surat pengantar yang dilakukan oleh warga secara langsung, terdapat juga fitur tersebut di halaman Ketua RT, tampilan form tambah surat dapat dilihat pada Gbr. 7, dintarnya adalah:

a) Textbox no kartu keluarga: Textbox ini digunakan untuk menginputkan data no kartu keluarga yang nantinya akan digunakan untuk verifikasi data.

b) Textbox NIK: Textbox ini digunakan untuk menginputkan data nik yang nantinya akan digunakan untuk verifikasi dan kebutuhan identitas surat. c) Combobox jenis surat: Combobox ini digunakan untuk menampilkan jenis-jenis surat pengantar yang dapat dipilih oleh warga sesuai dengan kebutuhanya.

d) Textbox tanggal: Textbox dengan type date ini digunakan untuk mempermudah menginputkan data tanggal kedalam sistem.

e) Textarea keterangan: Textarea ini digunakan untuk menampung data keterangan tambahan yang diperlukan untuk pendukung.

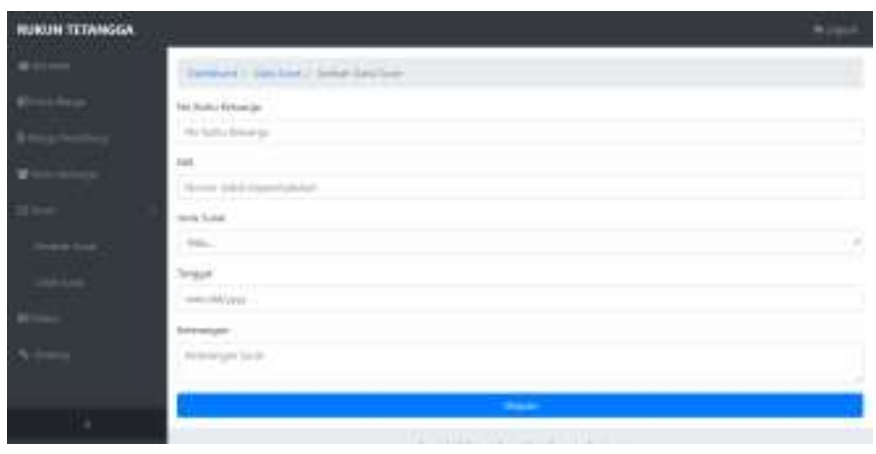

Gbr. 7 Halaman Tambah Surat Pengantar

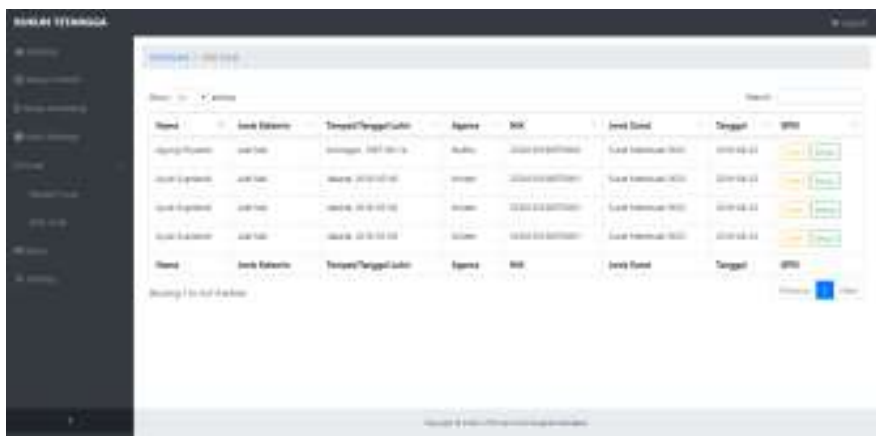

Gbr. 8 Halaman lihat surat

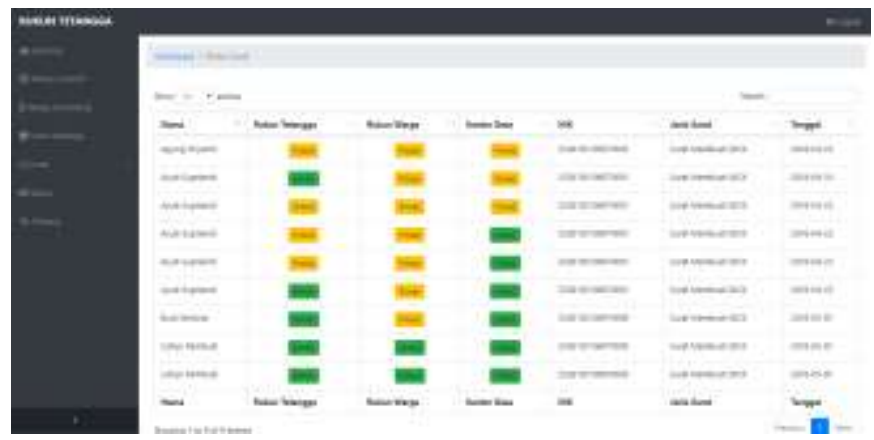

Gbr. 9 Halaman status surat

\section{3) Sub Menu Lihat Surat}

Pada halaman lihat surat terdapat tabel yang menampilkan data surat pengantar yang diajukan oleh warga yang data terdartar didalam sistem. Tampilan pada Gbr. 8.

a) Tombol Ubah: Tombol ini digunakan untuk mengubah data surat pengantar 
b) Tombol Setujui: Tombol ini digunakan untuk menyetujui surat pengantar

\section{4) Halaman Status}

Pada menu status berfungsi untuk menampilkan seluruh status surat pengantar, hal ini dimungkinkan untuk memberikan informasi tentang posisi sudah sampai mana proses permohonan pengajuan surat pengantar. Tampilan pada Gbr. 9.

\section{5) Tombol cetak surat}

Fitur ini digunakan pengguna untuk melakukan proses pencetakan surat sesuai dengan yang diajukan oleh warga, secara otomatis data surat sudah disesuaikan dengan yang ada di permohonan surat pengantar. Tampilan pada Gbr. 10 .

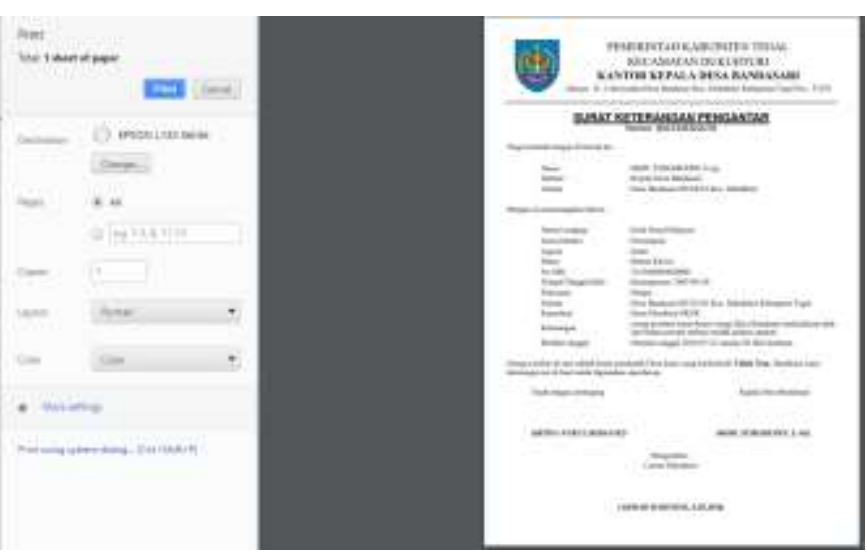

Gbr. 10 Halaman cetak surat pengantar

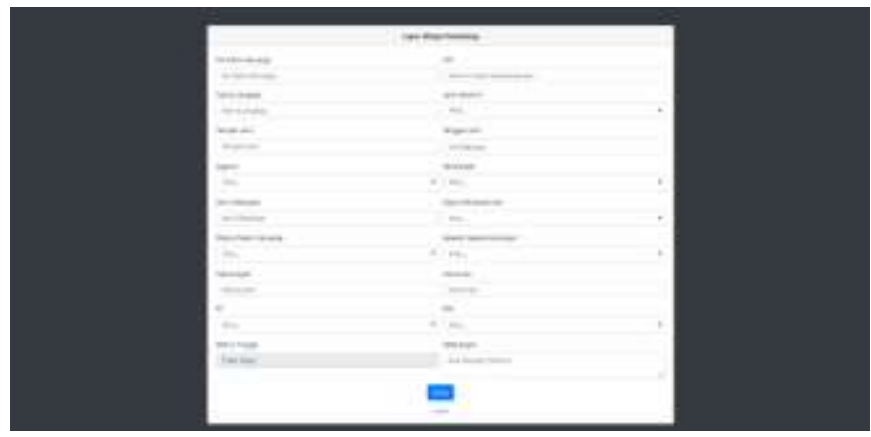

Gbr. 11 Halaman lapor warga pendatang

\section{6) Tombol Lapor Pendatang}

Fitur dari tombol ini digunakan oleh pengguna dalam hal ini adalah warga untuk melaporkan warga pendatang dengan memasukan data warga pendatang ke dalam sistem, sehingga pelaporan warga ini dapat di ketahui oleh Ketua RT, Ketua RW dan pihak Kantor Desa. Tampilan pada Gbr. 11.

\section{B. Hasil Pengujian Perangkat Lunak}

Pada hasil pengujian perangkat lunak, menjelaskan mengenai hasil dari pengujian yang dilakukan terhadap sistem kepada pengguna-pengguna yang nantinya akan menggunakan sistem ini. Pada pengujian perangkat lunak, metode yang dipilih oleh penulis adalah metode pengujian kotak hitam (black-box testing). Pada pengujian ini, dilakukan pengujian terhadap sejumlah fungsi yang terdapat pada perangkat lunak yang dikembangkan. Pengujian dilakukan oleh 9 orang penguji, dengan memberikan kuesioner penilaian. Hasil pengujian perangkat lunak dapat dilihat pada Tabel I.

TABEL I

HASIL PENGUJIAN TESTING SISTEM

\begin{tabular}{|c|c|c|c|c|c|c|c|c|}
\hline $\begin{array}{c}\text { Jenis } \\
\text { Pengujian }\end{array}$ & $\begin{array}{c}\text { Kantor } \\
\text { Desa }\end{array}$ & $\begin{array}{c}\text { Ketua } \\
\text { RW }\end{array}$ & $\begin{array}{c}\text { Ketua } \\
\text { RT }\end{array}$ & Wrg1 & Wrg2 & Wrg3 & Wrg4 & Wrg5 \\
\hline Login & $Y$ & $\mathrm{Y}$ & $\mathrm{Y}$ & & & & & \\
\hline $\begin{array}{l}\text { Melihat } \\
\text { surat } \\
\text { pengantar }\end{array}$ & $\mathrm{Y}$ & $\mathrm{Y}$ & $\mathrm{Y}$ & & & & & \\
\hline $\begin{array}{l}\text { Menambah } \\
\text { data warga }\end{array}$ & & & $\mathrm{Y}$ & & & & & \\
\hline $\begin{array}{l}\text { Mengajukan } \\
\text { surat } \\
\text { pengantar }\end{array}$ & & & & Y & $\mathrm{Y}$ & $\mathrm{Y}$ & Y & $\mathrm{Y}$ \\
\hline $\begin{array}{l}\text { Melaporkan } \\
\text { warga } \\
\text { pendatang }\end{array}$ & & & & Y & $\mathrm{Y}$ & $\mathrm{Y}$ & $\mathrm{Y}$ & $\mathrm{Y}$ \\
\hline $\begin{array}{l}\text { Menyetujui } \\
\text { surat } \\
\text { pengantar }\end{array}$ & Y & Y & $\mathrm{Y}$ & & & & & \\
\hline $\begin{array}{l}\text { Melihat } \\
\text { warga }\end{array}$ & $\mathrm{Y}$ & $\mathrm{Y}$ & $\mathrm{Y}$ & & & & & \\
\hline $\begin{array}{l}\text { Melihat } \\
\text { kartu } \\
\text { keluarga }\end{array}$ & $\mathrm{Y}$ & $\mathrm{Y}$ & $\mathrm{Y}$ & & & & & \\
\hline $\begin{array}{l}\text { Kelola data } \\
\text { pengguna }\end{array}$ & $\mathrm{Y}$ & & & & & & & \\
\hline $\begin{array}{l}\text { Mencetak } \\
\text { surat } \\
\text { pengatar }\end{array}$ & $\mathrm{Y}$ & & & & & & & \\
\hline
\end{tabular}

Keterangan:

a. Diterima (Y), mempunyai arti bahwa penguji setuju dengan hasil dan cara kerja dari fungsi fitur bagian sistem yang diuji.

b. Ditolak (T), mempunyai arti bahwa penguji menolak hasil dan cara kerja dari fungsi fitur bagian sistem yang diuji.

c. Kosong [ ], mempunyai arti bawah penguji tidak memiliki hak akses untuk menggunakan fitur yang diuji dari sistem informasi.

Pada pengujian yang sudah dilakukan berhasil mendapatkan respon dari para penguji. Bahwa pihak Kantor Desa setuju dengan hasil kinerja sistem pada fungsi Login, Melihat surat pengantar, Menyetujui surat pengantar, Melihat warga, Melihat kartu keluarga, Mengelola data pengguna, Mencetak surat pengantar. Selanjutnya ada Ketua RW yang setuju dengan hasil kinerja sistem pada fungsi Login, Melihat surat pengantar, Menyetujui surat pengantar, Melihat warga, Melihat kartu keluarga. Juga Ketua RT yang setuju dengan hasil kinerja sistem pada fungsi Login, Melihat surat pengantar, Menambah data warga, Menyetujui surat pengantar, Melihat warga, Melihat kartu keluarga. Dan terakhir pengujian kepada lima warga yang juga menyetujui hasil kinerja sistem pada fungsi Mengajukan surat pengantar dan Melaporkan warga pendatang.

Berdasarkan pembahasan pengujian diatas, dapat ditarik kesimpulan bahwa seluruh penguji setuju dengan cara kerja dan hasil kinerja sistem dari seluruh fungsi yang ada. Kemudian dari hasil pengujian dilakukan tanya pendapat responden untuk memberikan penilaian terhadap sistem yang 
telah dibangun. Diberikan beberapa pertanyaan dimana dalam tabel di simbolkan angka sesuai nomor urut dari pertanyaan di lembar kuisioner dan responden diberi pilihan nilai dari skala Likert [15] mulai dari $1-5$ yang merepresentasikan (1=Sangat Kurang, 2=Kurang, 3=Cukup, 4=Baik, 5=Sangat Baik) dan hasilnya dapat dilihat pada Tabel II.

TABEL II

RANGKUMAN HASIL KUISIONER

\begin{tabular}{|c|c|c|c|c|c|c|c|c|c|c|}
\hline No & Aeni & Baeti & Furadi & Windi & Lina & Fatkhi & Helmi & Arifatal & Purnandi & $\begin{array}{c}\text { Resa- } \\
\text { rata }\end{array}$ \\
\hline 1 & 4 & 5 & 5 & 4 & 4 & 4 & 5 & 5 & 5 & 5 \\
\hline 2 & 5 & 4 & 5 & 4 & 4 & 5 & 5 & 5 & 4 & 5 \\
\hline 3 & 5 & 4 & 4 & 4 & 4 & 5 & 5 & 4 & 4 & 4 \\
\hline 4 & 4 & 4 & 4 & 4 & 5 & 4 & 4 & 4 & 4 & 4 \\
\hline 5 & 4 & 5 & 5 & 5 & 5 & 4 & 4 & 4 & 4 & 4 \\
\hline 6 & 4 & 4 & 4 & 5 & 4 & 4 & 4 & 5 & 4 & 4 \\
\hline 7 & 4 & 4 & 4 & 4 & 4 & 4 & 4 & 5 & 4 & 4 \\
\hline 8 & 4 & 4 & 4 & 4 & 4 & 4 & 4 & 5 & 4 & 4 \\
\hline MaI & 34 & 34 & 35 & 34 & 34 & 34 & 35 & 37 & 33 & \\
\hline
\end{tabular}

Suara Responden

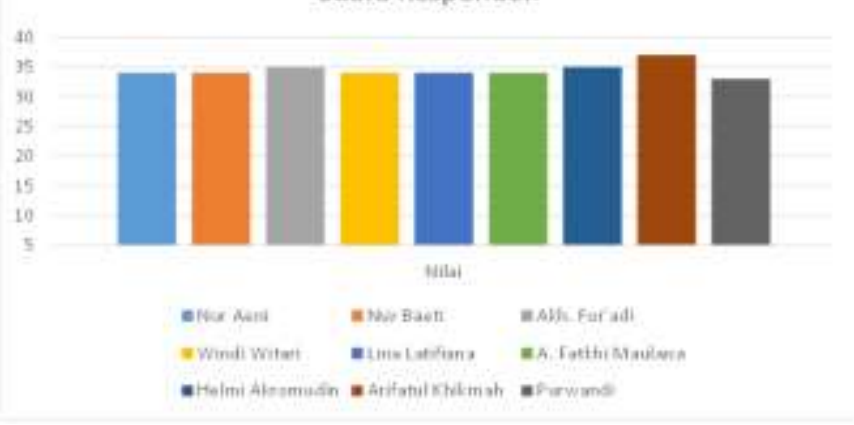

Gbr. 12 Diagram batang suara responden

Rata-rata Javaban dari Pertanyan

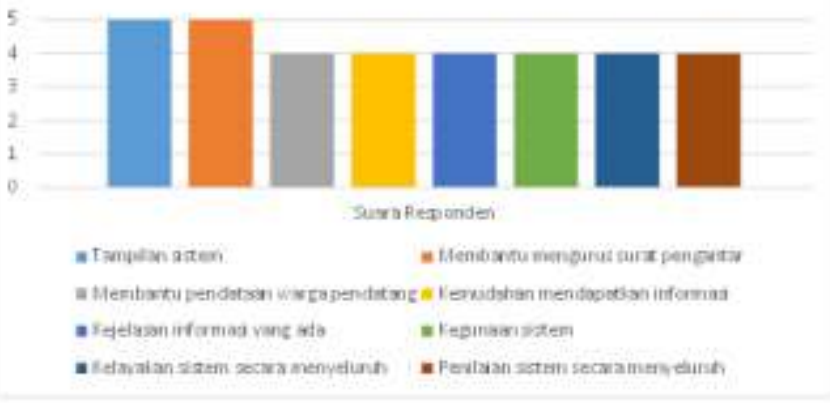

Gbr.13. Diagram rata-rata jawaban

Hasil jumlah seluruh jawaban dari masing-masing responden, dapat digambarkan dalam bentuk diagram batang seperti terlihat pada Gbr. 12. dimana Responden bernama Nur Aeni mempunyai total nilai 34 dari 40, Nur baeti 34 dari 40, Furadi 35 dari 40, Windi 34 dari 40, Lina 34 dari 40, Fatkhi 34 dari 40, Helmi 35 dari 40, Arifatul 37 dari 40, Purwandi 33 dari 40 .
Selain diagram pada masing-masing responden, digambarkan juga diagram pada masing-masing pertnayaan dimana total nilai adalah 5. Dan didapatkan rata-rata jawaban nilai pada masing-masing pertanyaan yaitu pada pertanyaan no 1 dan 2 mempunyai rata-rata 5 atau sangat Baik, sedangkan untuk pertanyaan no $3,4,5,6,7,8$ mendapat nilai rata-rata Baik pada masing-masing pertnayaan. Untuk lebih jelasnya dapat dilhat pada Gbr. 13 .

Dalam penelitian ini terdapat manfaat yang diharapkan dalam mengatasi permasalahan yang ada. Seperti pada penelitian ini adalah masalah waktu yang diharapkan dapat lebih efisien ketika menggunakan Sistem Informasi Pengurusan Surat Pengantar. Untuk itu dibawah ini adalah tabel penilitian hasil dari pengukuran waktu antara sebelum menggunakan sistem dan setelah menggunakan sistem.

TABEL III

PERBANDINGAN SEBELUM DAN SESUDAH MENGGUNAKAN SISTEM

\begin{tabular}{|c|c|c|}
\hline Nama Kegiatan & Sebelum & Sesudah \\
\hline $\begin{array}{l}\text { Proses pencarian } \\
\text { data warga }\end{array}$ & 35 Menit & 1 Menit \\
\hline $\begin{array}{l}\text { Proses pelaporan } \\
\text { warga pendatang }\end{array}$ & 20 Menit & 5 Menit \\
\hline $\begin{array}{l}\text { Proses } \\
\text { pengurusan surat } \\
\text { pengantar }\end{array}$ & $3 \mathrm{Jam}$ & 1,5 Jam \\
\hline $\begin{array}{lr}\text { Mencari } & \text { data } \\
\text { riwayat } & \text { surat } \\
\text { pengantar } & \\
\end{array}$ & 10 Menit & 1 Menit \\
\hline $\begin{array}{l}\text { Pembaruan data } \\
\text { warga }\end{array}$ & 20 Menit & 5 Menit \\
\hline
\end{tabular}

Pada Tabel III dijelaskan bahwa ketika melakukan proses pencarian data warga sebelum menggunakan sistem memerlukan waktu 35 menit, karena data berupa lembaran stopmap, namun setelah menggunakan sistem hanya membutuhkan waktu 1 Menit. Ketika melakukan pelaporan warga pendatang memerlukan waktu 20 menit karena pengguna harus melapor ke Rumah Ketua RT, namun setelah menggunakan sistem hanya membutuhkan waktu 5 menit, karena pengguna dapat melakukanya dari rumah. Proses pengurusan surat pengantar sebelum menggunakan sistem membutuhkan waktu 3 Jam, namun setelah menggunakan sistem hanya membutuhkan waktu 1,5 jam. Mencari data riwayat pengajuan surat pengantar sebelum menggunakan sistem membutuhkan waktu 10 menit, tetapi setelah menggunakan sistem hanya membutuhkan waktu 1 menit. Dan untuk proses pembaruan data warga sebelum menggunakan sistem membutuhkan waktu 20 menit, setelah menggunakan sistem membutuhkan waktu 5 menit.

Persentase kelayakan sistem hasil jawaban responden berdasarkan kuisioner yang diajukan kepada 9 responden menyatakan bahwa 8 dari 9 orang $(89 \%)$ memberikan nilai Baik dalam hal kelayakan sistem dan 1 dari 9 orang (11\%) menyatakan sangat layak dalam hal kelayakan sistem secara keseluruhan. Untuk lebih jelasnya dapat dilihat pada Tabel IV. 
Hasil representasi dari Tabel IV dapat kita lihat dalam bentuk Chart pada Gbr. 14. dimana warna biru menyatakan Layak dan warna orange menyatakan Sangat Layak.

TABEL IV

PERSENTASE KELAYAKAN SISTEM

\begin{tabular}{|l|c|c|c|c|c|c|}
\hline \multirow{2}{*}{ Kriteria } & \multicolumn{5}{|c|}{ Jawaban Responden } & \multirow{2}{*}{ Total } \\
\cline { 2 - 6 } & $\mathbf{1}$ & $\mathbf{2}$ & $\mathbf{3}$ & $\mathbf{4}$ & $\mathbf{5}$ & \\
\hline $\begin{array}{l}\text { Kelayakan sistem } \\
\text { secara menyeluruh }\end{array}$ & 0 & 0 & 0 & 8 & 1 & 9 \\
\hline
\end{tabular}

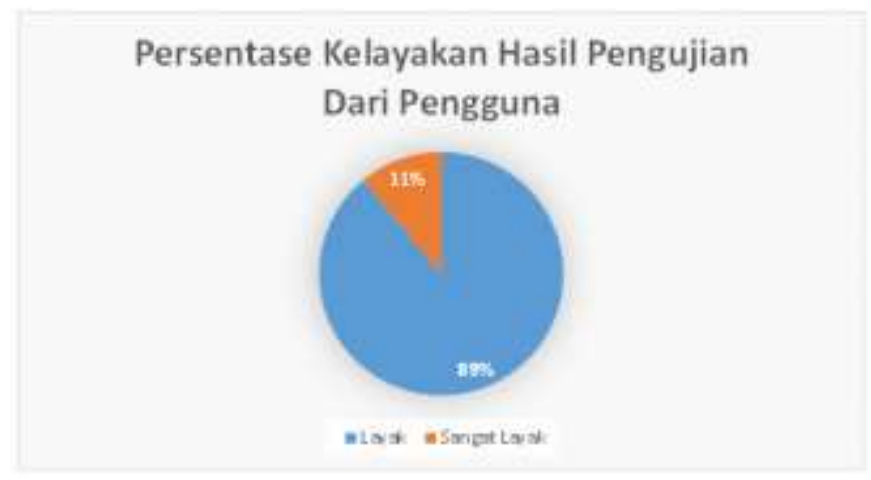

Gbr. 14 Chart Persentase Kalayakan Sistem

\section{KESIMPULAN}

Berdasarkan dari hasil pembahasan dan pengujian Sistem Informasi Pengurusan Surat Pengantar Desa Bandasari (SISUPER) di Desa Bandasari setelah di implementasikan dapat diambil kesimpulan bahwa yang pertama sistem Membantu pencatatan data warga secara terstruktur, sehingga proses pencarian data warga menjadi lebih mudah. Kedua membantu proses pencatatan warga pendatang menjadi lebih cepat. Ketiga membantu proses pengurusan surat pengantar menjadi lebih efisien. Keempat data riwayat pengurusan surat pengantar membantu Kepala Desa untuk melihat kinerja dari petugas desa, pejabat RT dan RW. Dan terakhir sistem memudahkan proses pembaruan data warga menjadi lebih cepat.

Hasil implementasi pengembangan Sistem Informasi Pengurusan Surat Pengantar Desa Bandasari (SISUPER) di Desa Bandasari masih perlu adanya penyempurnaan, yaitu Pengembangan selanjutnya dapat menambahkan pelayanan pengurusan surat ke tingkat yang lebih tinggi seperti kantor kecamatan. Bagi para peneliti yang akan mengembangkan sistem ini, dapat menambahkan tampilan grafik jumlah pengajuan surat pengantar pada setiap jenisnya yang ditampilkan berdasarkan per bulan. Terakhir Perlu ditambahkanya sebuah fitur pemberitahuan adanya pengajuan surat pengantar baru, baik pemberitahuan biasa maupun dengan layanan SMS gateway dan email gateway, sehingga
Bagian Ketua RT, Ketua RW, Bagian Desa menjadi lebih cepat prosesnya.

\section{UCAPAN TERIMA KASIH}

Puji syukur atas kehadirat Allah SWT dan tanpa mengurangi rasa hormat yang mendalam penulis mengucapkan terima kasih yang sebesar-besarnya kepada semua pihak yang telah membantu menyelesaikan penelitian ini, kepada Desa Bendasari Kecamatan Dukuhturi, Kabupaten Tegal-Jawa Tengah.

\section{DAFTAR PUSTAKA}

[1] A. Sarbini, A. R. Kusuma and A. Djumlani, "Implementasi Kebijakan Undang Undang Nomor 24 Tahun 2013 Tentang Administrasi Kependudukan Di Dinas Kependudukan Dan Pencatatan Sipil Kabupaten Kutai Kartanegara," eJournal Administrative Reform, vol. 4, no. (3), pp. 301-313, 2016.

[2] Y. Irawan, "Analisa Dan Perancangan Otomatisasi Surat Pengantar RT Berbasis SMS Gateway Sebagai Penerapan Konsep Paperless Office," Jurnal SIMETRIS, vol. 6, no. 1, pp. 175-182, 2015.

[3] R. Purwanto and A. R. Supriyono, "Sentralisasi Database Penduduk Desa Pandansari," Jurnal INFOTEKMESIN PNC, vol. 7, no. 1, pp. 5677, 2014.

[4] R. A.S and M. Shalahuddin, Rekayasa Perangkat Lunak: Terstruktur dan Berorientasi Objek, Bandung: Informatika, 2014.

[5] Junidar, "Perancangan Sistem Informasi Arsip Surat Menyurat Di Universitas U'budiyah Indonesia Menggunakan PHP dan Mysql," Universitas U'Budiyah Indonesia, Banda Aceh, 2012.

[6] A. D. Riyanto and I. Ma'ruf, "Perancangan SIstem Informasi Penjualan Komputer Berbasis Web," Jurnal Probisnis, vol. 7, no. 1, pp. 47-57, 2014 .

[7] Y. A. Binarso and N. B. Eko Adi Sarwoko, "Pembangunan Sistem Informasi Alumni Berbasis Web Pada Program Studi Teknik informatika universitas Diponegoro," Journal of Informatics and Technology, vol. 1, no. 1, pp. 72-84, 2012.

[8] E. M. Andrianti, Sulistiowati and T. Soebijono, "Rancang Bangun Aplikasi Penjualan Air Mineral Pada Toko Tirta Arlita Gresik," Jurnal Sistem Informasi dan Komputer Akuntansi, vol. 5, no. 12, pp. 1-5, 2016.

[9] A. Ibrahim and Musdiono, "Pengembangan Sistem Informasi Geografis Pemetaan Zona Banjir di Kota Palembang Berbasis Android," Jurnal Sistem Informasi, vol. 8, no. 2, pp. 1001-1014, 2016.

[10] T. A. Kurniawan, "Pemodelan Use Case (UML) : Evaluasi terhadap Beberapa Kesalahan Dalam Praktik," Jurnal Teknologi Informasi dan Ilmu Komputer, vol. 5, no. 1, pp. 77-86, 2017.

[11] E. Triandini and I. G. Suardika, Step by Step Desain Proyek Menggunakan UML, Yogyakarta: Penerbit Andi, 2012.

[12] K. Arif and A. Ambarita, "Sistem Pengolahan Data Rekam Medis Berbasis Web Pada Puskesmas Perawatan Jambula Kota Ternate," Indonesian Journal on Information System, vol. 1, no. 2, pp. 68-77, 2016.

[13] R. Ramadi, "Penerapan Knowledge Management System Pada Perusahaan Otomotif : Studi Kasus PT. Astrido Jaya Mobilindo," Jurnal SIMETRIS, vol. 7, no. 2, pp. 635-648, 2016.

[14] Jubilee Enterprise , Membuat Website PHP dengan CodeIgniter, Jakarta: PT. Elex Media Komputindo, 2015.

[15] Maryuliana, I. M. I. Subroto and S. F. C. Haviana, "Sistem Informasi Angket Pengukuran Skala Kebutuhan Materi Pembelajaran Tambahan Sebagai Pendukung Pengambilan Keputusan di Sekolah Menengah Atas Menggunakan Skala Likert," Jurnal Transistor Elektro dan Informatika, vol. 1, no. 2, pp. 1-12, 2016. 